\title{
A comparison of the artificial pancreas (glucose controlled insulin infusion system) and a manual technique for assessing insulin sensitivity during euglycaemic clamping
}

\author{
M. Ponchner, R. J. Heine, A. Pernet, I.Hanning, A. J. Francis, D.Cook, H.Ørskov' and K. G. M. M. Alberti \\ Department of Clinical Biochemistry and Metabolic Medicine, Royal Victoria Infirmary, Newcastle upon Tyne, UK and \\ 'Afdelung M, Kommunehospital, Aarhus, Denmark
}

Summary. Two main methods are available for assessing insulin sensitivity with the hyperinsulinaemic euglycaemic clamp technique: one employs a glucose-controlled insulin infusion system (the Biostator) with automatic feedback control; the second depends on frequent glucose measurement and the use of an algorithm and a pocket calculator ('manual') to determine the glucose infusion rate. The amount of glucose infused is a measure of insulin sensitivity. The efficiency of the two methods was compared in nine normal subjects (seven lean, two obese). After an overnight fast subjects were infused with insulin at $50 \mathrm{mU} \cdot \mathrm{kg}^{-1} \cdot \mathrm{h}^{-1}$ for $2 \mathrm{~h}$; this rate was doubled during the first $10 \mathrm{~min}$ for the manual technique. Blood glucose averaged $4.7 \pm 0.1$ and $4.8 \pm 0.1 \mathrm{mmol} / 1$ from 0 to $120 \mathrm{~min}$ for Biostator and manual techniques and did not deviate significantly from the desired level. Variability of the clamp was also similar over the same period (coefficient of variation $5.1 \pm 0.6 \%$ and $6.4 \pm 0.7 \%$, Biostator and manual). Glucose infused to maintain steady state from 60 to $120 \mathrm{~min}$ was higher, however, with the manual than the Biostator method $\left(5.7 \pm 0.6\right.$ versus $\left.4.4 \pm 0.6 \mathrm{mg} \cdot \mathrm{kg}^{-1} \cdot \mathrm{min}^{-1}, p<0.01\right)$ even when the loading dose was omitted, although the two methods correlated closely $(p<0.05)$. Glucose infusion rate varied more from minute to minute with the Biostator (coefficient of variation $28.8 \pm 3 \%$ versus $12.2 \pm 2.1 \%$ ). Steady-state serum insulin levels $(30-120 \mathrm{~min}$ ) were the same during both methods. Thus both methods give effective clamping but the manual method is simpler and shows less variability in glucose insulin infusion rate.

Key words: Glucose clamping, artificial pancreas, insulin infusion, insulin sensitivity, glucose disposal.
The euglycaemic hyperinsulinaemic clamp technique allows insulin to be infused without alteration of blood glucose levels [1-4]. In this situation endogenous insulin production is largely suppressed and hepatic glucose production is minimal $[1,5]$. Thus the amount of glucose needed to maintain blood glucose levels at the fasting value equals the uptake of glucose by all tissues and serves as a measure of insulin sensitivity. Two main methods are available for performing the technique: one employs the 'artificial endocrine pancreas' (Biostator) with automatic feedback control $[2,3,6]$; the second depends on frequent glucose measurement and the use of an algorithm and a pocket calculator $[1,7]$ to determine the glucose infusion rate. We have compared the two methods with respect to efficiency of glucose clamping, variability of glucose infusion rate and glucose metabolized. Serum insulin levels, suppressibility of endogenous insulin secretion and cortisol, glucagon and intermediary metabolite responses were also assessed.

\section{Subjects and methods}

\begin{abstract}
Subjects
Nine healthy volunteers (six males, three females) ranging in age from 21 to 37 years (mean $29 \pm 1$ years) were studied. Seven were within $10 \%$ of desirable body weight [8] and the other two were $121 \%$ and $137 \%$. They were asked to maintain their normal diet for 3 days before the study and to fast for 10-12 $\mathrm{h}$ before study. No subject was taking any medication. Each subject was studied on two separate occasions with at least one week between them. The order of the studies was randomized. Five subjects had a second manual clamp 4 weeks later, omitting the priming dose.

The study was approved by the local Ethical Committee and informed consent was obtained from all subjects.
\end{abstract}

\section{Protocol}

On the morning of the study, three polytetrafluoroethylene cannulae (Venflon, Viggo, Helsingborg, Sweden) were inserted. One cannula, in an antecubital vein, was used for intermittent blood sampling for hormone and metabolite levels and was flushed with saline, $0.15 \mathrm{~mol} / 1$, after use. A second cannula, inserted retrogradely with the tip posi- 
tioned in a dorsal hand vein, was used for continuous sampling and blood glucose measurement of arterialised blood by the Biostator. Arterialisation of venous blood was achieved by maintaining the hand at approximately $55^{\circ} \mathrm{C}$ in a thermoregulated Plexiglas box [9]. The third cannula, in the contralateral antecubital vein, was used for all infusions. A period of $1 \mathrm{~h}$ elapsed before starting the infusion in order to complete calibration of the Biostator and to achieve stability of the glucose sensor response. Thereafter (time $0 \mathrm{~min}$ ) the subjects were infused for $120 \mathrm{~min}$ with highly-purified porcine insulin (Actrapid, Novo) in polygeline (Haemaccel, Hoechst UK, Hounslow) at $0.05 \mathrm{U}$. $\mathrm{kg}^{-1} \cdot \mathrm{h}^{-1}$ using a Harvard pump (Harvard Apparatus, South Natick, Massachussetts, USA). This infusion rate was doubled from 0 to 10 min during the manual technique (primed).

\section{Biostator method}

The following constants were used: BSD (selected glucose level) was set at fasting glucose level minus $0.3 \mathrm{mmol} / 1$ to remove any influence of endogenous insulin secretion; QD (inverse of the static gain for glucose infusion) was 5 until the clamp glucose value was reached at which time it was increased to $20 ; \mathrm{RD}$ (glucose infusion rate at selected glucose level BSD) was $50 \mathrm{mg} / \mathrm{min}$ until the clamp value was attained, and afterwards increased to $100 \mathrm{mg} / \mathrm{min}$ or more as necessary. The concentration of the glucose solution was $40 \mathrm{~g} / \mathrm{dl}(2.22 \mathrm{~mol} / \mathrm{l})$. An additional infusion of glucose between 75 and $150 \mathrm{mg} / \mathrm{min}$ was given through the saline channel as glucose solutions of 20 or $40 \mathrm{~g} / \mathrm{dl}$ (1.11 or $2.22 \mathrm{~mol} / \mathrm{l})$. To conduct the glucose clamp, mode $7: 1$ of the preprogrammed algorithm was used, according to the following equation:

$\mathrm{DR}($ glucose infusion rate $)=\mathrm{RD} \frac{(\mathrm{BSD}-\mathrm{G}+1)^{4}}{\mathrm{QD}}$

$\mathrm{G}=$ last 4-min average glucose level

\section{Manual method}

Blood glucose values, obtained with the Biostator (used purely as a glucose monitor), were read every $5 \mathrm{~min}$ and fed into a preprogrammed Texas Instruments 57 Calculator (Dallas, USA). Glucose $40 \mathrm{~g} / \mathrm{dl}(2.22 \mathrm{~mol} / \mathrm{l})$ was infused by a variable-infusion-rate, two-syringe pump (Vickers Treonic, Vickers Medical, Basingstoke, UK). A continuous infusion of saline $0.15 \mathrm{mmol} / 1$ at approximately $1 \mathrm{ml} / \mathrm{min}$ was delivered through an intravenous infusion set connected with the glucose infusion line. The glucose infusion rate was modified according to the following equation, which is derived from that originally described by DeFronzo et al. [1]:

$\mathrm{Si}=\left((\mathrm{Gd}-\mathrm{Gi}) \times 0.13+\mathrm{SM}_{\mathrm{i}-2} \times \mathrm{FM}_{\mathrm{i}} \times \mathrm{FM}_{\mathrm{i}-1}\right) \times \mathrm{K}$,

where Gd is the desired glucose level, which is the basal glucose value $(\mathrm{Gb})$ in $\mathrm{mg} / \mathrm{dl}$;

$\mathrm{Gi}$ is the current blood glucose concentration at any time $(\mathrm{mg} / \mathrm{dl})$; $\mathrm{G}$ inf $=$ glucose concentration in the infusate $(\mathrm{mg} / \mathrm{ml})$;

$\mathrm{SMi}=\mathrm{SM}_{\mathrm{i}-2} \times \mathrm{FM}_{\mathrm{i}} \times \mathrm{FM}_{\mathrm{i}-1}=$ current metabolic component (mg. $\left.\mathrm{kg}^{-1} \cdot \mathrm{h}^{-1}\right)$

$\mathrm{SM}_{\mathrm{i}-2}=$ 'metabolic' component two iterations previously (10 min);

$\mathrm{FM}_{\mathrm{i}}=\mathrm{Gb} / \mathrm{Gi} ; \mathrm{FM}_{\mathrm{i}-1}=\mathrm{Gb} / \mathrm{Gi}$ one iteration previously $(5 \mathrm{~min})$;

$K=\frac{\mathrm{kg} \text { body weight } \times \mathrm{PF}}{\mathrm{G} \text { inf }}$, converting the infusion rate of glucose

from $\mathrm{mg} \cdot \mathrm{kg}^{-1} \cdot \mathrm{min}^{-1}$ to the corresponding infusion rate of the pump in $\mathrm{ml}(\mathrm{PF}=$ pump factor, converting the infusion rate from $\mathrm{ml} / \mathrm{min}$ to the setting of the pump).

The initial values selected were $\mathrm{SM}_{\mathrm{i}-2}=4 \mathrm{mg} \cdot \mathrm{kg}^{-1} \cdot \mathrm{min}^{-1}$ and $\mathrm{FM}_{\mathrm{i}-1}=1$ as described in the original method [1].

The glucose infusion was started at $+4 \mathrm{~min}$ at $2 \mathrm{mg} \cdot \mathrm{kg}^{-1} \cdot \mathrm{min}^{-1}$ and continued until $+11 \mathrm{~min}$. The $10-\mathrm{min}$ blood glucose value was the first one fed into the calculator and the estimated infusion rate was initiated at $+11 \mathrm{~min}$. Subjects with higher insulin sensitivity, defined as a decrease in the blood glucose value of more than $0.3 \mathrm{mmol} / 1$ in
$5 \mathrm{~min}$, were given an extra infusion of approximately $3 \mathrm{mg} \cdot \mathrm{kg}^{-1}$. $\min ^{-1}$ between +15 and +20 in addition to the amount estimated by the algorithm. This was given as glucose $(2.22 \mathrm{~mol} / \mathrm{l})$ by a Harvard pump connected with the variable-infusion-pump line. This supplementary infusion was maintained until $+120 \mathrm{~min}$.

Blood for lactate, pyruvate, alanine, glycerol and 3-hydroxybutyrate was taken into chilled perchloric acid $(0.5 \mathrm{~mol} / \mathrm{l})$ and the extract stored at $-20^{\circ} \mathrm{C}$ until analysis by fluorimetric methods [10]. Serum insulin was measured by double-antibody radioimmunoassay [11] (sensitivity $2 \mathrm{mU} / 1$; intra-assay coefficient of variation 7\%), using human insulin as standard. C-peptide was measured by radioimmunoassay with ethanol precipitation [12] (sensitivity $0.02 \mathrm{nmol} / \mathrm{l}$, within assay coefficient of variation $3 \%$ ). Serum cortisol and plasma glucagon [13] were estimated by radioimmunoassay.

\section{Calculations}

The ' $M$ ' value represents the glucose metabolised during the steadystate period from $60-120 \mathrm{~min}$ with corrections for changes in glucose pool size as described previously [1].

Stability of the clamp was assessed by: (a) the coefficient of variation of blood glucose, and (b) the coefficient of variation of glucose infusion rate. Results are expressed as mean \pm SEM, and comparisons have been made using Student's t-test for paired samples unless otherwise indicated.

\section{Results}

\section{Blood glucose}

The mean basal blood glucose values were similar before the Biostator and manual techniques (5.0 0.1 versus $4.8 \pm 0.1 \mathrm{mmol} / \mathrm{l}, \mathrm{NS})$, as were mean values from

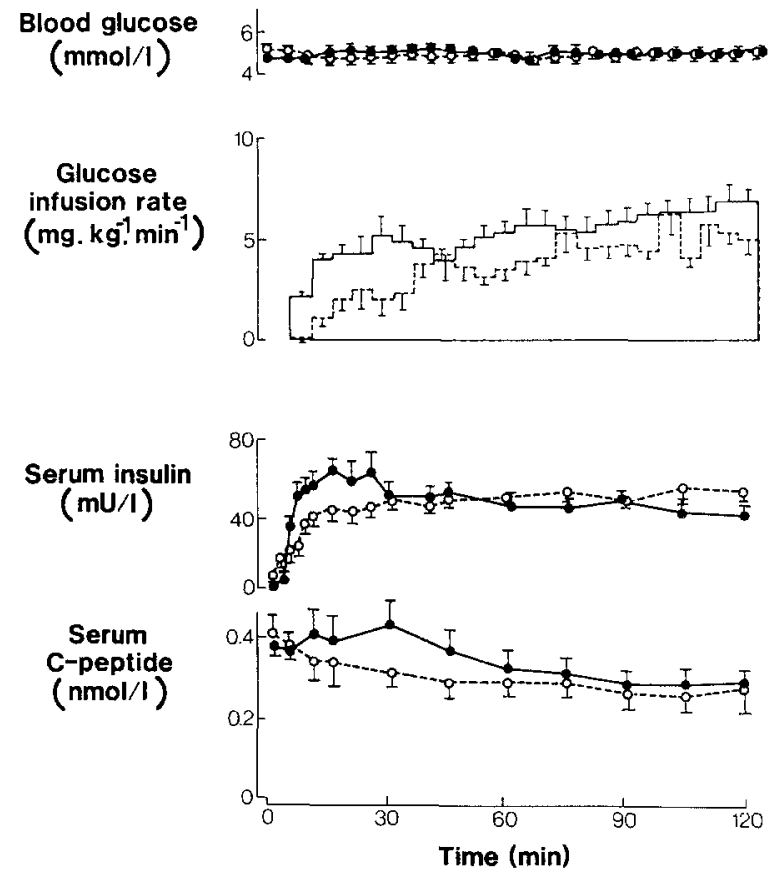

Fig. 1. Blood glucose, glucose infusion rate, serum insulin and C-peptide during euglycaemic clamping by the Biostator and primed manual technique. $\longrightarrow$ manual technique, $\mathrm{O}_{---O} \mathrm{O}$ Biostator technique. Results are shown as mean \pm SEM 
Table 1. Euglycaemic hyperinsulinaemic clamp: individual data $(60-120 \mathrm{~min})$

\begin{tabular}{|c|c|c|c|c|c|c|c|c|c|c|c|c|}
\hline $\begin{array}{l}\text { Sub- } \\
\text { ject }\end{array}$ & \multicolumn{4}{|l|}{ Biostator } & \multicolumn{4}{|c|}{ 'Primed' manual technique } & \multicolumn{4}{|c|}{ 'Unprimed' manual technique } \\
\hline 1 & 4.5 & 8.2 & 5.0 & 44.8 & 4.8 & 4.4 & 8.6 & 5.9 & - & - & - & - \\
\hline 2 & 5.1 & 9.2 & 5.9 & 39.4 & 4.7 & 6.2 & 6.1 & 14.9 & - & - & - & - \\
\hline 5 & 4.8 & 4.0 & 2.6 & 15.5 & 4.6 & 9.2 & 5.3 & 27.3 & 4.2 & 3.8 & 3.7 & 22.1 \\
\hline 6 & 4.1 & 3.7 & 3.7 & 18.1 & 4.2 & 4.1 & 6.3 & 11.6 & - & - & - & - \\
\hline 7 & 4.2 & 5.6 & 6.2 & 28.2 & 4.1 & 4.9 & 6.2 & 11.9 & - & - & - & - \\
\hline $8^{b}$ & 5.3 & 2.1 & 2.6 & 17.1 & 5.0 & 2.1 & 2.9 & 9.2 & 5.5 & 1.6 & 3.2 & 11.5 \\
\hline $9^{b}$ & 4.7 & 2.0 & 2.5 & 23.1 & 4.4 & 1.4 & 2.5 & 10.3 & 4.8 & 4.1 & 4.3 & 11.7 \\
\hline
\end{tabular}

a $\mathrm{CV}=$ coefficient of variation; ${ }^{\mathrm{b}}$ subjects 8 and 9 were the two overweight patients

Table 2. Comparison of the Biostator and manual primed hyperinsulinaemic euglycaemic clamp technique

\begin{tabular}{|c|c|c|c|c|}
\hline Variable & $\begin{array}{l}\text { Time } \\
(\mathrm{min})\end{array}$ & $\begin{array}{l}\text { Biostator } \\
\text { clamp } \\
(n=9)\end{array}$ & $\begin{array}{l}\text { Manual } \\
\text { clamp } \\
(n=9)\end{array}$ & $p$ \\
\hline $\begin{array}{l}\text { Blood glucose } \\
(\mathrm{mmol} / \mathrm{l})\end{array}$ & $\begin{array}{r}0-120 \\
60-120\end{array}$ & $\begin{array}{l}4.7 \pm 0.1 \\
4.7 \pm 0.1\end{array}$ & $\begin{array}{l}4.8 \pm 0.1 \\
4.7 \pm 0.1\end{array}$ & $\begin{array}{l}\text { NS } \\
\text { NS }\end{array}$ \\
\hline $\begin{array}{l}\text { Coefficient of varia- } \\
\text { tion of blood glucose } \\
(\%)\end{array}$ & $\begin{array}{r}0-120 \\
60-120\end{array}$ & $\begin{array}{l}5.1 \pm 0.6 \\
5.0 \pm 0.8\end{array}$ & $\begin{array}{l}6.4 \pm 0.7 \\
4.4 \pm 0.8\end{array}$ & NS \\
\hline $\begin{array}{l}\text { Blood glucose } \\
\text { (\% of desired value) }\end{array}$ & $60-120$ & $99.6 \pm 1.2$ & $98.2 \pm 0.7$ & $\mathrm{NS}$ \\
\hline $\begin{array}{l}\text { Glucose infusion rate } \\
\left(\mathrm{mg} \cdot \mathrm{kg}^{-1} \cdot \mathrm{min}^{-1}\right)\end{array}$ & $0-120$ & $3.4 \pm 0.4$ & $4.8 \pm 0.5$ & $<0.001$ \\
\hline $\begin{array}{l}\text { Steady-state glucose } \\
\text { infusion rate } \\
\text { (M value; } \\
\left.\mathrm{mg} \cdot \mathrm{kg}^{-1} \cdot \mathrm{min}^{-1}\right)\end{array}$ & $60-120$ & $4.5 \pm 0.6$ & $5.7 \pm 0.6$ & $<0.05$ \\
\hline $\begin{array}{l}\text { Coefficient of varia- } \\
\text { tion of glucose } \\
\text { infusion rate }(\%)\end{array}$ & $60-120$ & $28.8 \pm 3.6$ & $12.2 \pm 2.1$ & $<0.01$ \\
\hline Serum insulin $(\mathrm{mU} / \mathrm{l})$ & $30-120$ & $52 \pm 4$ & $51 \pm 5$ & NS \\
\hline $\begin{array}{l}\text { C-peptide suppression } \\
\text { (\% of basal value) }\end{array}$ & $60-120$ & $35 \pm 6$ & $22 \pm 6$ & NS \\
\hline
\end{tabular}

Results expressed as mean \pm SEM

0 to $120 \mathrm{~min}(4.7 \pm 0.1$ versus $4.8 \pm 0.1 \mathrm{mmol} / \mathrm{l}$; NS) (Fig. 1, Tables 1 and 2). Expressed in percentage terms they were $99.6 \pm 1.2 \%$ and $98.2 \pm 0.7 \%$ of the intended clamp values for Biostator and manual techniques (NS). The stability of the blood glucose concentrations during both techniques is shown in Figure 1 and is expressed as the coefficient of variation of blood glucose in Tables 1 and $2(5.1 \pm 0.6 \%$ versus $6.4 \pm 0.7 \%$ from 0 to $120 \mathrm{~min}$ and $5.0 \pm 0.8 \%$ versus $4.4 \pm 0.8 \%$ from 60 to $120 \mathrm{~min}$ for Biostator and manual techniques respectively, NS).

\section{Serum insulin}

The mean basal serum insulin concentrations shown in Figure 1 were similar before the Biostator $(7 \pm 2 \mathrm{mU} / \mathrm{l})$ and the manual clamps $(6 \pm 1 \mathrm{mU} / 1, \mathrm{NS})$. There was an overshoot of the serum insulin values from 5 to $30 \mathrm{~min}$ during the manual technique, related to the priming dose of insulin (Fig.1). The increase of insulin concentration at the beginning of the Biostator technique was smoother and slower reaching a plateau around $30 \mathrm{~min}$, simultaneously with the manual method. The mean serum insulin concentrations were similar for both methods from 30 to $120 \mathrm{~min}(52 \pm 4$ and $51 \pm 5 \mathrm{mU} / \mathrm{l}$; Table 2).

\section{Serum C-peptide}

Serum C-peptide levels are shown in Figure 1. The values were similar before the two insulin infusions and showed a steady fall during both methods. At $120 \mathrm{~min}$ the mean C-peptide suppression from basal values expressed as a percentage was $35 \pm 6 \%$ for the Biostator and $22 \pm 6 \%$ for the manual method (NS).

\section{Glucose disposal ( $M$ value)}

The glucose disposal from 60 to $120 \mathrm{~min}$ was significantly higher for the manual technique: $4.5 \pm 0.6$ versus $5.7 \pm 0.6 \mathrm{mg} \cdot \mathrm{kg}^{-1} \cdot \mathrm{min}^{-1}(p<0.05)$, although the two methods correlated closely $\left(\mathrm{r}_{\mathrm{s}}, 0.72 ; p<0.05\right)$ (Table 2). The coefficient of variation of the average infusion rate assessed each $5 \mathrm{~min}$ was significantly higher with the Biostator technique $(28.8 \pm 3.6 \%$ compared with $12.2 \pm$ $2.1 \%, p<0.01$ ).

In order to clarify to what extent the initial priming dose of insulin of the manual technique could have determined the higher glucose disposal observed with this method, five of the nine original subjects underwent a second euglycaemic clamp using the manual technique. On this occasion, the priming dose of insulin was omit- 
Table 3. Comparison between Biostator and 'unprimed' manual euglycaemic clamp. Five subjects were studied on two occasions

\begin{tabular}{|c|c|c|c|c|}
\hline Variable & $\begin{array}{l}\text { Time } \\
\text { (min) }\end{array}$ & $\begin{array}{l}\text { Biostator } \\
\text { clamp } \\
(n=5)\end{array}$ & $\begin{array}{l}\text { Unprimed } \\
\text { manual } \\
\text { clamp } \\
(n=5)\end{array}$ & $p$ \\
\hline $\begin{array}{l}\text { Blood glucose } \\
(\mathrm{mmol} / \mathrm{l})\end{array}$ & $\begin{array}{r}0-120 \\
60-120\end{array}$ & $\begin{array}{l}4.9 \pm 0.1 \\
4.9 \pm 0.1\end{array}$ & $\begin{array}{l}4.7 \pm 0.3 \\
4.6 \pm 0.3\end{array}$ & $\begin{array}{l}\text { NS } \\
\text { NS }\end{array}$ \\
\hline $\begin{array}{l}\text { Coefficient of varia- } \\
\text { tion of blood glucose } \\
(\%)\end{array}$ & $\begin{array}{r}0-120 \\
60-120\end{array}$ & $\begin{array}{l}4.0 \pm 0.5 \\
3.6 \pm 0.8\end{array}$ & $\begin{array}{l}6.1 \pm 0.7 \\
3.9 \pm 0.8\end{array}$ & $\begin{array}{l}\text { NS } \\
\text { NS }\end{array}$ \\
\hline $\begin{array}{l}\text { Blood glucose } \\
\text { (\% desired) value }\end{array}$ & $60-120$ & $99.3 \pm 1.2$ & $97.0 \pm 0.6$ & NS \\
\hline $\begin{array}{l}\text { M value } \\
\left(\mathrm{mg} \cdot \mathrm{kg}^{-1} \cdot \mathrm{min}^{-1}\right)\end{array}$ & $60-120$ & $4.0 \pm 0.9$ & $5.0 \pm 0.8$ & $<0.005$ \\
\hline $\begin{array}{l}\text { Coefficient of varia- } \\
\text { tion of glucose } \\
\text { infusion rate }(\%)\end{array}$ & $60-120$ & $25.7 \pm 4.6$ & $14.4 \pm 3.2$ & NS \\
\hline Serum insulin $(\mathrm{mU} / \mathrm{l})$ & $30-120$ & $56 \pm 6$ & $50 \pm 6$ & NS \\
\hline $\begin{array}{l}\text { C-peptide suppression } \\
\text { (\% of basal value) }\end{array}$ & $0-120$ & $27 \pm 11$ & $29 \pm 7$ & NS \\
\hline
\end{tabular}

Results expressed as mean \pm SEM
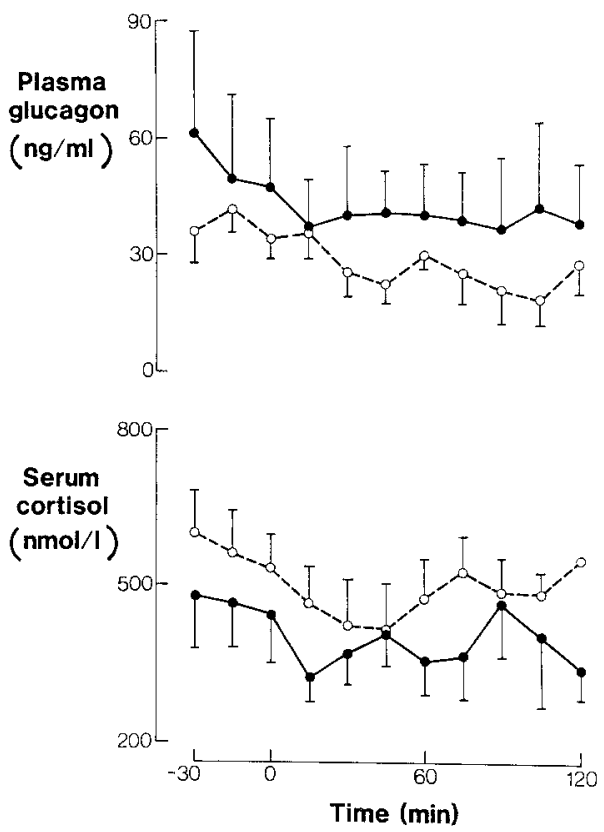

Fig. 2. Plasma glucagon and serum cortisol concentrations during euglycaemic clamping by the Biostator and primed manual technique. - manual technique, $\mathrm{O}_{---} \mathrm{O}$ Biostator technique. Results are shown as mean \pm SEM

ted. The results are summarised in Table 3. Once again a significantly higher $M$ value was noticed during the manual technique $\left(5.0 \pm 0.8\right.$ versus $4.0 \pm 0.9 \mathrm{mg} \cdot \mathrm{kg}^{-1}$. $\min ^{-1}, p<0.05$ ), despite similar values for mean blood glucose percent of that desired, mean serum insulin and mean percentage of C-peptide suppression.

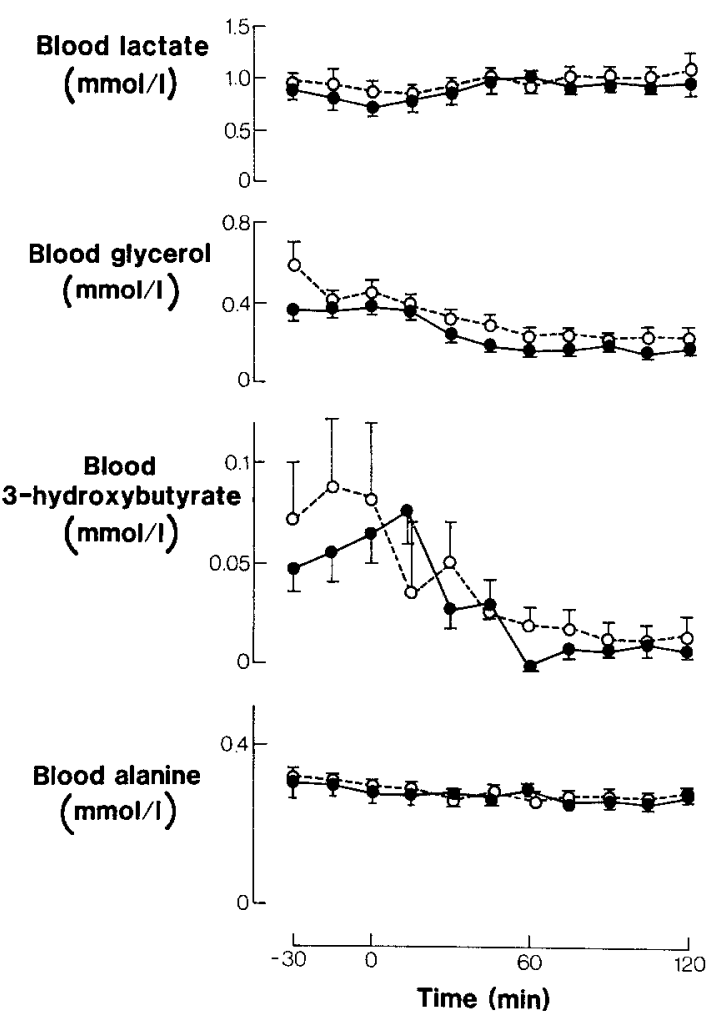

Fig.3. Blood lactate, glycerol, 3-hydroxybutyrate and alanine concentrations during euglycaemic clamping by the Biostator and primed manual technique. $\longrightarrow$ manual technique, $\mathrm{O}_{---} \mathrm{O}$ Biostator technique. Results are shown as mean \pm SEM

\section{Serum cortisol}

Figure 2 shows that there was no significant difference at any time point between cortisol values using the two methods.

\section{Plasma glucagon}

The blood samples of six of the subjects were assayed for glucagon. Values decreased during the first $30 \mathrm{~min}$, plateauing at levels which were $23.2 \pm 9.6 \%$ and $25.5 \pm$ $7.0 \%$ below basal for manual and Biostator techniques respectively (Fig. 2, NS).

\section{Blood metabolite responses}

The changes in metabolite concentration during both techniques are shown in Figure 3. Blood lactate and pyruvate levels showed little change with either technique. Blood alanine decreased slightly and similarly in both studies. The basal levels of glycerol and 3-hydroxybutyrate were slightly higher for the Biostator technique but decreased to similar values with both methods. 
Table 4. Blood intermediary metabolite levels before and after 2 -h Biostator and manual euglycaemic clamps

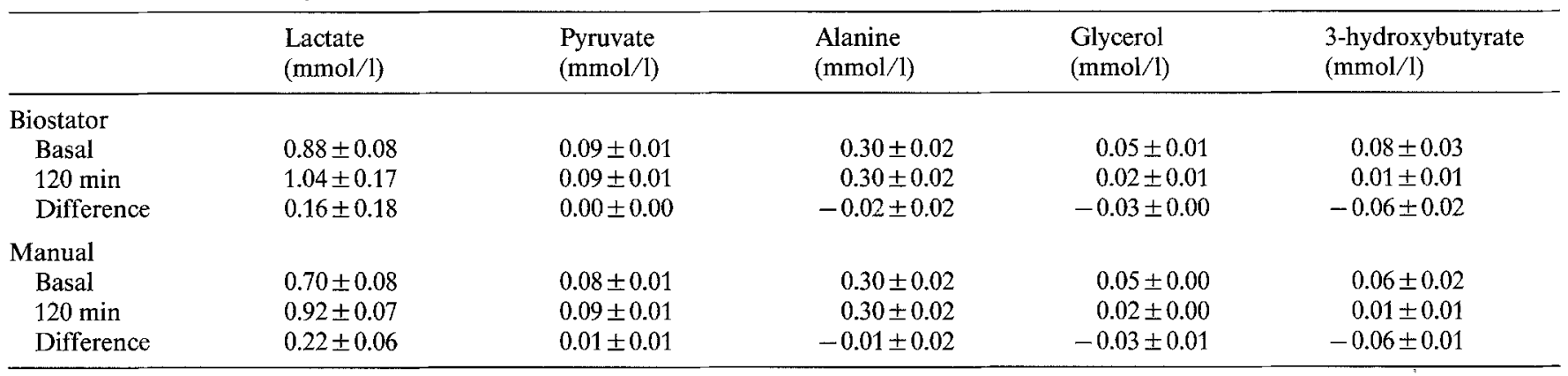

Results expressed as mean \pm SEM. Nine subjects studied

\section{Discussion}

The results presented demonstrate that both the Biostator and the manual techniques give effective glucose clamping, but the manual method does not require complex machines and shows less variability in glucose infusion rate.

After pilot experiments, we found it necessary to introduce modifications to the originally-published manual feedback technique [1]. Instead of an insulin infusion rate of $40 \mathrm{mU} / \mathrm{m}^{2}$ surface area per min we have chosen a dose of $0.05 \mathrm{U} / \mathrm{kg}$ body weight per hour. At this dose hepatic glucose production is almost completely suppressed according to previous studies $[4,14]$, and thus under steady-state conditions of euglycaemia the glucose infusion rate equals glucose uptake by the body tissues and is a measurement of insulin sensitivity. On the other hand, at this dose endogenous insulin production is inhibited, as demonstrated by the significant suppression of C-peptide basal levels in this and previous studies $[2,3]$.

In the initial experiments a priming dose of insulin was given over the first $10 \mathrm{~min}$. This resulted in an overshoot of insulin levels as mentioned by the original authors [1], despite a complicated minute-to-minute logarithmically-decreasing rate of insulin infusion. The plateau of hyperinsulinaemia was reached at the same time (30 min) in the five unprimed manual studies and using the Biostator when no priming dose was used and no overshoot of serum insulin levels was produced. Thus the priming dose of insulin is unnecessarily complicated and is not required.

We have also simplified the original glucose infusion equation given by DeFronzo [1] to one in which we first calculate the infusion rate in $\mathrm{mg} \cdot \mathrm{kg}^{-1} \cdot \mathrm{min}^{-1}$ and then convert this to the appropriate pump setting. This allows the investigator to have a much better idea of what requirements of glucose are needed at that particular moment. This algorithm was not capable of coping with the rapidly increasing glucose requirements in the first half hour after starting the insulin infusion in the more insulin sensitive subjects. This problem was overcome by giving an extra glucose infusion of approximately $3 \mathrm{mg} \cdot \mathrm{kg}^{-1} \cdot \mathrm{min}^{-1}$, in addition to the amount in- dicated by the equation. This infusion rate was arbitrarily chosen and was only initiated when a decline in the glucose levels of more than $0.3 \mathrm{mmol} / 1$ was seen within $5 \mathrm{~min}$ during the first $20 \mathrm{~min}$. It was then continued until $120 \mathrm{~min}$.

For calculation of glucose disposal (M value) the period from 60 to 120 min was selected because this was the period in which the variability of the glucose infusion rate and blood glucose levels was least.

Two striking features emerged: first, infusion rates were more variable with the Biostator clamps; and second, $M$ values were consistently higher with the manual technique. The significantly higher variability of infusion rates by the Biostator compared with the manual clamp technique can be explained by the characteristics of the Biostator feedback mechanism. The infusion rate of glucose is changed each minute according to the average blood glucose value of the last $4 \mathrm{~min}$, and the algorithm contains a term raised to the fourth power, resulting in marked changes in infusion rates with minimal alterations in blood glucose levels.

One possible cause of the higher glucose disposal rate during the manual clamp was the priming dose of insulin. This was excluded by the second series of clamps in which the priming dose was omitted, and the $M$ value remained unaltered. A possible explanation might be the static algorithm of the Biostator which is not capable of changing the glucose infusion rate adequately in a non-steady-state situation as in the first hour of a glucose clamp. For this the RD has to be adjusted arbitrarily, which interrupts the feedback system and glucose delivery each time. This causes a delay in reaching a steady state in the glucose delivery rate, whereas during the manual clamp a steady state was achieved in the first hour after starting the insulin infusion (Fig. 1). The difference in glucose disposal rate tended to decrease during the 2 -h glucose clamp. Despite this difference both methods correlated closely.

The Biostator method $[2,3,6]$ has some disadvantages over the manual technique: more expensive equipment is needed; continuous blood sampling is subject to error and there is drift of the immobilised glucose oxidase membrane [6]. More recently we have used a glucose analyser (model 26 AM; Yellow Springs In- 
struments, Yellow Springs, Ohio, USA) for measuring whole blood glucose. This provides results in $40 \mathrm{~s}$ and the instrument can be calibrated before reading each 5 -min sample. This overcomes the problem of sampling obstructions and changes in the glucose analyser membrane sensitivity. The Biostator technique is not entirely automated and requires the development of expertise. After simplifying the manual technique, the manpower requirements are similar for both techniques: one trained operator.

Previous studies have used empirical adjustments in glucose infusion rate in order to perform the euglycaemic clamp technique [4]. We agree that this could be done but requires the development of greater expertise and hence a long period of training.

The results show an absence of counter-regulatory response of cortisol and glucagon (Fig. 2). This clearly demonstrates the advantage over the earlier hypoglycaemic insulin sensitivity techniques [5]. The latter procedure elicits the secretion of glucagon, cortisol, growth hormone and catecholamines, which vary from individual to individual and according to the rate of fall of glucose, hence making the interpretation of results difficult.

As expected, the response of the intermediary metabolites was similar during both techniques and followed the patterns described in previous studies $[2,3]$. Glycerol and 3-hydroxybutyrate levels decreased, reflecting suppression of lipolysis and ketogenesis by insulin as reported previously $[2,3,17]$.

Acknowledgements. We are grateful to the British Council, the British Diabetic Association, Novo Industri and Suisse Fonde de Recherche for financial support. We are also grateful to Mrs. M. Brown, Dr. A.W. Hodson, Dr. J. M. Burrin, Mrs. L. Ashworth, Mr. I. Anderson and Dr. P.D.Home for expert advice and assistance.

\section{References}

1. DeFronzo RA, Tobin JD, Andres R (1979) Glucose clamp technique: a method for quantifying insulin secretion and resistance. Am J Physiol 237: E214-223

2. Home PD, Massi-Benedetti M, Shepherd GAA, Hanning I, Alberti KGMM, Owens D (1982) A comparison of the activity and disposal of semi-synthetic human insulin and porcine insulin in man by the glucose clamp technique. Diabetologia 22:41-45

3. Massi-Benedetti M, Burrin JM, Capaldo B, Alberti KGMM (1981) A comparative study of the activity of E. coli-derived hu- man insulin and porcine insulin using the glucose clamp technique in normal man. Diabetes Care 4: 163-167

4. Rizza R, Mandarino LJ, Gerich JE (1981) Mechanisms of insulin resistance in man. Assessment using the insulin dose-response curve in conjunction with insulin-receptor binding. Am $\mathrm{J}$ Med 70: $169-176$

5. Olefsky $J$ (1981) Insulin resistance and insulin action. An in vitro and in vivo perspective. Diabetes 30:148-163

6. Verdonk CA, Rizza RA, Westland RE, Nelson RL, Gerich JE, Service $J J$ (1980) Glucose clamping using the Biostator GCIIS. Horm Metab Res 12: 133-135

7. Andres R, Swerddoff R, Pozefsky T, Coleman D (1966) Manual feedback technique for the control of blood glucose concentration. In: Skeggs LT (ed) Automation in analytical chemistry. Mediad, New York, pp 486 491

8. Diem K (ed) (1959) Desirable weight of adults, 6th edn. Documenta Geigy, Macclesfield, p 624

9. Abumrad N, Rabin D, Diamond M, Lacy W (1981) Use of heated superficial hand vein as alternative site for the measurement of aminoacid concentrations and for the study of glucose and alanine kinetics. Metabolism 30: 936-940

10. Lloyd B, Burrin JM, Smythe P, Alberti KGMM (1978) Simple automated fluorimetric assays for blood glucose, lactate, pyruvate, alanine, glycerol and 3-hydroxybutyrate. Clin Chem 24: 1724-1729

11. Soeldner J, Slone D (1965) Critical variables in the radioimmunoassay of serum insulin using the double antibody technic. Diabetes 14: 771-779

12. Heding LG (1975) Radioimmunological determination of human C-peptide in serum. Diabetologia 11: 541-548

13. Ørskov H, Thomsen HG, Yde H (1968) Wick chromatography for rapid and reliable immunoassay of insulin, glucagon and growth hormone. Nature 219: 193-195

14. Sacca L, Sherwin R, Hendler R, Felig P (1979) Influence of continuous physiologic hyperinsulinemia on glucose kinetics and counterregulatory hormones in normal and diabetic humans. J Clin Invest $63: 849-857$

15. Olefsky JM, Kolterman OG (1981) Mechanisms of insulin resistance in obesity and non-insulin dependent (Type II) diabetes. Am J Med 70: 151-168

16. DeFronzo RA, Andres R, Bledsoe T, Boden G, Faloona GA, Tobsin TD (1977) A test of the hypothesis that the rate of fall in glucose concentration triggers counterregulatory hormonal responses in man. Diabetes 26: 445-452

17. Schade DS, Eaton RP (1977) Dose response to insulin in man: differential effects on glucose and ketone body regulation. J Clin Endocrinol Metab 44: 1038-1053

Received: 10 February 1983

and in revised form: 17 February 1984

Professor K. G. M. M. Alberti

Department of Clinical Biochemistry and Metabolic Medicine

Royal Victoria Infirmary

Newcastle upon Tyne NE1 4LP

UK 